\title{
The Study of Causality of Teacher's Turnover Intention at Private Junior High School
}

\author{
Eddy Setyanto ${ }^{a}$, Hardianto ${ }^{b}$, \\ ${ }^{a}$ Universitas Indraprasta PGRI, Jakarta, Awardee LPDP, ${ }^{\mathrm{b}}$ Universitas Pasir Pengaraian \\ Email eddy.setyanto@gmail.com ; hardiantocally@gmail.com
}

Article History: Received: 10 November 2020; Revised 12 January 2021; Accepted: 27 January 2021; Published online: 5 April 2021

\begin{abstract}
Purpose: Identify the direct effect of reward, motivation and job satisfaction on the turnover intention the teacher. Design/methodology: This study used a quantitative approach with a survey method. The data was taken by using questionnaire and analyzed by using path analysis. The research sample was 149 private junior high school teachers in Rokan Hulu District. The sample were taken by using simple random sampling technique. Findings: The results of the study showed that the reward has a direct negative effect on turnover intention. Motivation has a direct negative effect on turnover intention, job satisfaction has a direct negative effect on turnover intention. Research limitations/implications: The research sample was taken from schools in Rokan Hulu Regency, therefore it is necessary to be careful to generalize the results of this study in a wider scope such as for the province or a country.Practical implicaations: Based on the results of the study, it was known that to reduce teacher turnover intention private junior high school can be done by increasing their reward, motivation and job satisfaction.
\end{abstract}

Keywords: Turnover intention, Reward, Motivation, Job satisfacation, Teacher

\section{Introduction}

The high-performance teachers are needed for achieving the education goal. It can be seen if the teacher are enjoying to work. It can be seen from teachers whe they do not turnover intention. There were 49 cases of teachers turnover at private junior high school $(20.85 \%)$ on 2017 in Rokan Hulu Regency.

Based on the data, there were 7 cases of turnover in Rambah Subdistrict, there were 6 cases in Kepenuhan district, there were 9 cases in Ujung Batu Subdistrict, there were 14 cases in Tandun Subdistrict, there were 4 cases in Tambusai Subdistrict, there were 3 cases in Tambusai Utara subdistrict, there were 2 cases in Kabun subdistrict, there were 3 cases in Bonai Darussalam subdistrict and there was 1 case in Kepenuh Hulu Subdistrict.

The high teacher turnover rate can hinder the achievement of educational goals. Therefore it is necessary to look at the factors that influence the teacher's turnover. Turnover occurs when the teacher has the desire to turnover intention. Intention to turnover is a good and reliable predictor of actual turnover behavior. Intention to quit is the immediate precursor of actual withdrawal behavior (Youcef et al., 2016) 
The Private junior high school teacher are getting salary about 300,000 rupiahs per month in Rokan Hulu Regency. Some schools pay teacher salaries every three months or when the School Operational Assistance (BOS) funds are disbursed. This number is clearly still far from enough to fulfill the daily needs. Lack of salary received can cause teachers to have the desire to do turnover. This study examines a range of school conditions as well as demographic factors and finds that high levels of school turnover are strongly affected by poor working conditions and low salaries, as well as by student characteris (Loeb, Hammond \& Luczak, 2005). Some of the results of the study state that reward affect turnover intention (Cao et al., 2013) .

They also rarely get training and attending seminars. Participating in training and seminars can increase the motivation of teachers to work. Teachers who have the motivation to work and don't have the desire to leave. The end results of this study indicate that training and development (intrinsic factor of motivation) opportunities have very strong inverse relationship with employee's intention to quit (Imran M, 2017). Kwame, Mahama, Boahen \& Denu, (Kunu et al., 2017) study states that lack of motivation is one of the factors causing labor turnover in Zoomlion Ghana Limited. Another study by Vnouckova and Klupakova ( 2013) also mentions that The results below show that a lack of motivation principles leads to employee dissatisfaction and disaffection and may cause employee turnover

Job satisfaction affects the desire to turnover intention teachers. Teachers who are satisfied with work are certainly happy with their work and do not have the intention to move from that job. This is in accordance with (Tnay et al., 2013) research which shows that satisfaction has a negative and significant effect on employee turnover intention with a value of $r=-0.234$. The research results of Youcef et al (2016) also state that there is a negative and significant influence between the variables of job satisfaction on turnover intention with a value of $r=-$ 0.129. The research result Ingersoll (2001) states that the data show that the amount of turnover accounted for by retirement is relatively minor when compared to that associated with other factors, such as teacher job dissatisfaction and teachers pursuing other jobs. Based on the phenomenon of the problem, it should be assumed that reward, motivation and job satisfaction affect the teacher's turnover intention.

\section{Literature review}

Turnover intention is the most reliable indicator after measuring actual turnover. Thus, it is important to understand the factors affecting turnover intentions in order to understand actual turnover rates and patterns (Duraisingam et al., 2009). Turnover is voluntary and involuntary permanent withdrawal from an organization(Robbins et al., 2012). Turnover is the number of employees who have left the company divided by the employees who remain, expressed in a percentage. It can be very costly, almost double the leaving employee's annual salary, due to recruiting, retraining, and lost productivity (Gilley et al., 2015).

Many factors cause turnover. Turnover is a complex process and is affected by variables (e.g., economic conditions, family considerations) that have little to do with the job or the organization (Jex and Britt, 2008). Turnover can be due to a variety of factors. Employees leave 
for a variety of reasons, such as retirement, resignation, or termination. Generally, a company would prefer to keep high performing, talented employees while only losing employees that are underperforming (Gilley et.al, 2009).

Turnover occurs when people quit their jobs. An organization usually incurs costs in replacing workers who have quit, and if turnover involves especially productive people, it is even more costly. Turnover seems to result from a number of factors, including aspects of the job, the organization, the individual, the labor market, and family influences (Griffin and Moorhead, 2014). Some of the financing that will arise with turnover is:

a) Direct cost of recruiting replacements (advertising, interviewing, testing, etc).

b) Direct cost of introducing replacements (induction cost).

c) Direct cost of training replacements in necessary skills.

d) Leaving costs - payroll and HR administration.

e) Opportunity cost of time spent by HR and line managers in recruitment, induction and training.

f) Loss of output from those leaving before they are replaced.

g) Loss of output because of delays in obtaining replacements.

h) Loss of output while new starters are on their learning curves acquiring the necessary knowledge and skills (Armstrong, 2009)

A reward is something that is perceived as desirable by the recipient and is obtained as a result of some action. If it is not perceived as positive, then it isn't rewarding to the recipient. If it is not obtained as a result of some action, it is a gift or good fortune, not a reward (McCoy, 1992). Reward is the old total remuneration concept of pay and benefits combined with non-financial recognition and motivation and applied in a contemporary HRM context (Pilbeam adn Marjorie, 2006). The concept of reward is to have some sort of multiple helix, where motivation, skill, career and performance are all intertwined to produce added value to the individual career and corporate aspects, with the pay reflecting, describing and moving with the other elements continuously (Torrington, Hall and Taylor, 2005).

Rewards affects to turnover intention. Turnover intention can be reduced by increasing the level of pay structure (Mendis, 2017). Rewards can affect such individual behaviors as turnover, absenteeism, performance, and commitment (Gibson et.al, 2012; Jex and Britt, 2008). The benefits accruing 'from a total reward scheme are easier recruitment of better quality staff, reduced wastage from staff turnover, better business performance and the enhanced reputation of the organisation as an employer of choice' (Pilbeam and Marjorie, 2006).

Motivation also influence turnover intention. Because they show high levels of motivation, commitment and organizational citizenship, they adopt better-performing behaviours, leading to lower absenteeism and turnover rates, increased productivity and higher levels of quality (Armstrong, 2009). Motivation gave the significant effect toward turnover. There was regretion coeficient -922, it means that there was a negative effect (Sajjad, Ghazanfar \& Ramzan, 2013). Motivation is the set of forces that causes people to engage in one behavior rather than some alternative behavior (Griffin and Moorhead, 2014). In addition, motivation is an internal state 
of the individual that influences the direction, intensity, and persistence of behavior (Illgen and sheppard, 2001). 63.20\% of teacher motivation contributes to the quality of education (Gobena, 2018).

Job satisfaction also gave the effect toward turnover intention. Job satisfaction is the extent to which a person is gratified or fulfilled by his or her work (Griffin and Moorhead, 2014). Satisfaction is the form in which one experiences having gained or possessed a value (Locke, 2009). The employers who feel enjoying toward their job, they would not quit from their job. Satisfied and committed employees have lower rates of turnover, absenteeism, and withdrawal behaviors (Robbins, Judge \& Timothy, 2013). Although job satisfaction doesn't influence quantity and quality of performance, it does influence citizenship behaviors, turnover, absenteeism, and preferences and opinions about unions (Gibson, Ivancevich, Donelly \& Konopaske, 2012).

\section{Methodology}

The population of study were private junior high school teachers in Rokan Hulu District, they were 235 teachers. Sample of the research were 149 teachers that was obtained by using Slovin formula. Sample of the research was taken by using simple random sampling technique.

\begin{tabular}{|l|c|c|}
\hline \multicolumn{1}{|c|}{ Name of School } & Population & Sample \\
\hline SMP Islam Terpadu Inayah & 12 & 8 \\
\hline SMP Muhammadiyah Ujung Batu & 12 & 8 \\
\hline SMP Advent & 13 & 7 \\
\hline SMP Kita Membangun & 11 & 7 \\
\hline SMP S Yadika Km 40 Mahato & 11 & 6 \\
\hline SMP Libo Ceria & 10 & 10 \\
\hline SMP Islam Kepenuhan & 16 & 4 \\
\hline SMP S Kepenuhan Sejati & 6 & 6 \\
\hline SMP LPMD Kabun & 9 & 6 \\
\hline SMP Pilar Padura Harapan & 9 & 7 \\
\hline SMP LPMD Puo Raya & 11 & 8 \\
\hline SMP Salafiah Babussalam & 12 & 6 \\
\hline SMP LPMD Kumain & 9 & 6 \\
\hline SMP S Eka Dura Lestari & 10 & 6 \\
\hline SMP KM Yadika Tambusai & 9 & 8 \\
\hline SMP YTPP Hutahaean & 13 & 20 \\
\hline SMP IT Khalid bin Walid & 32 & 8 \\
\hline SMP Muhammadiyah Rambah & 13 & 4 \\
\hline SMP LPMD Sukamaju & 7 & $\mathbf{1 4 9}$ \\
\hline SMP Tiga Hati & $\mathbf{2 3 5}$ & \\
\hline & & 6 \\
\hline
\end{tabular}

Tabel 1. Distribution of Population and research sample 
The study used a survey method with a quantitative approach. Data retrieval was done with a questionnaire that has been tested for validity and reliability. Validity test was done by Pearson product moment formula, while reliability test used Cronbach formula. Data Analysis Techniques used path analysis.

The recapitulation of the validity and reliability of the instruments is presented in the following table.

\begin{tabular}{|l|c|c|c|}
\hline \multicolumn{1}{|c|}{$\begin{array}{c}\text { Research } \\
\text { Instrument }\end{array}$} & $\begin{array}{c}\text { Item } \\
\text { tried out }\end{array}$ & $\begin{array}{c}\text { Item } \\
\text { valid }\end{array}$ & $\begin{array}{c}\text { Cronbach } \\
\text { coefecient }\end{array}$ \\
\hline $\begin{array}{l}\text { Turnover } \\
\text { Intention }\end{array}$ & 38 & 33 & 0,942 \\
\hline Reward & 40 & 33 & 0,941 \\
\hline Motivation & 38 & 32 & 0,936 \\
\hline Job Satisfaction & 38 & 34 & 0,942 \\
\hline
\end{tabular}

Table 2. Instrument Validity and Reliability

The hypothesis this study are:

a) There is a direct negative effect of rewards toward turnover intention

b) There is a direct negative effect of motivation toward turnover intention

c) There is a direct negative effect of job satisfaction toward turnover intention

The hypothetical model of this research is

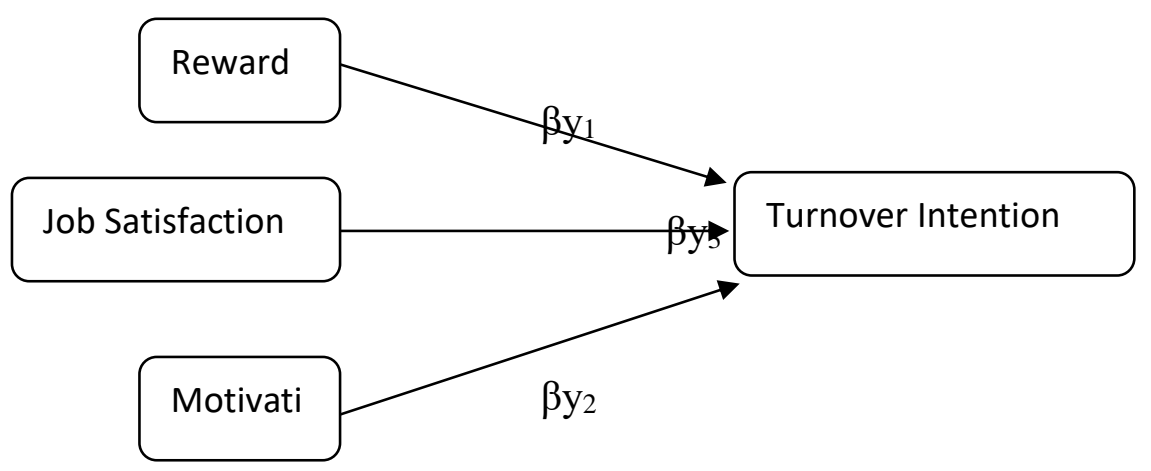

Figure 1 Research Hypothetic Model

\section{Result}

Based on the results of the study it is known that the description of the turnover intention variable data is as follows: Mean 132.35; Median 132.00; 132.00 mode; Deviation Standard 5,29; Sample variance 27.97; Range 23; Minimum score 121 and Maximum score 144. The frequency distribution of the turnover intention variable scores is explained in the following table 


\begin{tabular}{|c|ccc|c|c|c|}
\hline \multirow{2}{*}{ No } & \multicolumn{2}{|}{ Interval class } & \multicolumn{3}{|c|}{ Frequency } \\
\cline { 3 - 7 } & \multicolumn{2}{|c}{} & Absolute & Comulative & Relative \\
\hline 1 & 121 & - & 123 & 8 & 8 & $5,37 \%$ \\
\hline 2 & 124 & - & 126 & 14 & 22 & $9,40 \%$ \\
\hline 3 & 127 & - & 129 & 24 & 46 & $16,11 \%$ \\
\hline 4 & 130 & - & 132 & 35 & 81 & $23,49 \%$ \\
\hline 5 & 133 & - & 135 & 28 & 109 & $18,79 \%$ \\
\hline 6 & 136 & - & 138 & 20 & 129 & $13,42 \%$ \\
\hline 7 & 139 & - & 141 & 13 & 142 & $8,72 \%$ \\
\hline 8 & 142 & - & 144 & 7 & 149 & $4,70 \%$ \\
\hline & \multicolumn{3}{|r|}{} & 149 & & $100 \%$ \\
\hline
\end{tabular}

Table 3. The Distribution of Turnover Intention variable frequency

Based on the results of the study it is known that the description of the reward variable data is as follows: Mean 127.65; Median 128.00; 132.00 mode; Deviation Standard 5,88; Sample variance 34.62; Range 30; Minimum score 112 and Maximum score 142. The frequency distribution of the reward variable scores is explained in the following table

\begin{tabular}{|c|ccc|c|c|c|}
\hline \multirow{2}{*}{ No } & \multirow{2}{*}{ Interval Class } & \multicolumn{3}{|c|}{ Frequency } \\
\cline { 2 - 6 } & \multicolumn{2}{|c}{ Absolute } & Comulative & Relative \\
\hline 1 & 112 & - & 115 & 3 & 3 & $2,01 \%$ \\
\hline 2 & 116 & - & 119 & 11 & 14 & $7,38 \%$ \\
\hline 3 & 120 & - & 123 & 25 & 39 & $16,78 \%$ \\
\hline 4 & 124 & - & 127 & 27 & 66 & $18,12 \%$ \\
\hline 5 & 128 & - & 131 & 39 & 105 & $26,17 \%$ \\
\hline 6 & 132 & - & 135 & 32 & 137 & $21,48 \%$ \\
\hline 7 & 136 & - & 139 & 9 & 146 & $6,04 \%$ \\
\hline 8 & 140 & - & 143 & 3 & 149 & $2,01 \%$ \\
\hline & & & & $\mathbf{1 4 9}$ & & $\mathbf{1 0 0 \%}$ \\
\hline
\end{tabular}

Table 4. The Distribution of Reward Variable frequency 
Based on the results of the study it is known that the description of the motivation variable data is as follows: Mean 126.34; Median 126.00; 129.00 mode; Deviation Standard 5,29; Sample variance 27.96; Range 23; Minimum score 115 and Maximum score 138. The frequency distribution of the motivation variable scores is explained in the following table

\begin{tabular}{|c|ccc|c|c|c|}
\hline \multirow{2}{*}{ No } & \multirow{2}{*}{ Interval Class } & \multicolumn{3}{|c|}{ Frequency } \\
\cline { 2 - 6 } & \multicolumn{2}{|c}{115} & - & Absolute & Comulative & Relative \\
\hline 1 & & & 9 & 9 & $6,04 \%$ \\
\hline 2 & 118 & - & 120 & 13 & 22 & $8,72 \%$ \\
\hline 3 & 121 & - & 123 & 22 & 44 & $14,77 \%$ \\
\hline 4 & 124 & - & 126 & 33 & 77 & $22,15 \%$ \\
\hline 5 & 127 & - & 129 & 29 & 106 & $19,46 \%$ \\
\hline 6 & 130 & - & 132 & 25 & 131 & $16,78 \%$ \\
\hline 7 & 133 & - & 135 & 15 & 146 & $10,07 \%$ \\
\hline 8 & 136 & - & 138 & 3 & 149 & $2,01 \%$ \\
\hline & & & & $\mathbf{1 4 9}$ & & $\mathbf{1 0 0 \%}$ \\
\hline
\end{tabular}

Table 5. The Distribution of Motivation variable Frequency

Based on the results of the study it is known that the description of the job satisfaction variable data is as follows: Mean 134.87; Median 135.00; 136.00 mode; Deviation Standard 4,88; Sample variance 23.79; Range 22; Minimum score 123 and Maximum score 145. The frequency distribution of the job satisfaction variable scores is explained in the following table

\begin{tabular}{|c|ccc|c|c|c|}
\hline \multirow{2}{*}{ No } & \multirow{2}{*}{ Interval Class } & \multicolumn{3}{|c|}{ Frequency } \\
\cline { 2 - 6 } & \multicolumn{2}{|c}{} & Absolute & Comulative & Relative \\
\hline 1 & 123 & - & 125 & 7 & 7 & $4,70 \%$ \\
\hline 2 & 126 & - & 128 & 9 & 16 & $6,04 \%$ \\
\hline 3 & 129 & - & 131 & 18 & 34 & $12,08 \%$ \\
\hline 4 & 132 & - & 134 & 32 & 66 & $21,48 \%$ \\
\hline 5 & 135 & -137 & 35 & 101 & $23,49 \%$ \\
\hline 6 & 138 & -140 & 30 & 131 & $20,13 \%$ \\
\hline
\end{tabular}




\begin{tabular}{|c|ccc|c|c|c|}
\hline 7 & 141 & -143 & 13 & 144 & $8,72 \%$ \\
\hline 8 & 144 & -146 & 5 & 149 & $3,36 \%$ \\
\hline & & & & $\mathbf{1 4 9}$ & & $\mathbf{1 0 0 \%}$ \\
\hline
\end{tabular}

Table 6. The Distribution of Job Satisfaction Variable Fequency

Before the hypothesis testing was done, first test analysis requirements are carried out consisting of normality test, linearity test and significance test. Hypothesis testing can be done if the data is normally distributed, forming a linear and significant line. Based on the results of the study it is known that the data are normally distributed and linear and significant. Recapitulation of the results of the normality test and linearity test and significance can be seen in the following table:

\begin{tabular}{|c|l|c|c|c|c|c|}
\hline \multirow{2}{*}{ No } & \multirow{2}{*}{$\begin{array}{c}\text { Estimated Error } \\
\text { Regretion }\end{array}$} & \multirow{2}{*}{$\mathbf{n}$} & \multirow{2}{*}{ Lcal } & \multicolumn{2}{|c|}{ Ltable } & \multirow{2}{*}{ Information } \\
\cline { 5 - 6 } & & & & $\boldsymbol{\alpha}=\mathbf{5 \%}$ & $\boldsymbol{\alpha}=\mathbf{1 \%}$ & \\
\hline 1 & $\mathrm{Y}$ atas $\mathrm{X}_{1}$ & 149 & 0,0334 & 0,0726 & 0,0845 & Normal \\
\hline 2 & $\mathrm{Y}$ atas $\mathrm{X}_{2}$ & 149 & 0,0513 & 0,0726 & 0,0845 & Normal \\
\hline 3 & $\mathrm{Y}$ atas $\mathrm{X}_{3}$ & 149 & 0,0496 & 0,0726 & 0,0845 & Normal \\
\hline
\end{tabular}

Table 7. Normality Test

\begin{tabular}{|c|c|c|c|c|c|c|}
\hline \multirow{3}{*}{ Reg } & \multirow{3}{*}{ equation } & \multicolumn{2}{|c|}{$\begin{array}{l}\text { Significan } \\
\text { Testing }\end{array}$} & \multicolumn{2}{|c|}{$\begin{array}{l}\text { Linierity } \\
\text { Testing }\end{array}$} & \multirow{3}{*}{ Conclusion } \\
\hline & & \multirow{2}{*}{$\mathbf{F}_{\text {cal }}$} & $F_{\text {table }}$ & \multirow{2}{*}{$F_{\text {cal }}$} & \multirow{2}{*}{$\begin{array}{l}F_{\text {table }} \\
\alpha=0,05\end{array}$} & \\
\hline & & & $\alpha=0,01$ & & & \\
\hline $\begin{array}{l}\mathrm{Y} \text { atas } \\
\mathrm{X}_{1}\end{array}$ & $\begin{array}{l}\widehat{Y}=186,810+- \\
0,427 X_{1}\end{array}$ & 42,95 & $6,81 * *$ & 0,975 & $1,59^{\mathrm{ns}}$ & $\begin{array}{l}\text { Regretion is very } \\
\text { significan/ } \\
\text { Linearity Regretion }\end{array}$ \\
\hline $\begin{array}{l}\mathrm{Y} \text { atas } \\
\mathrm{X}_{2}\end{array}$ & $\begin{array}{l}\widehat{Y}=192,302+- \\
0,475 X_{2}\end{array}$ & 42,88 & $6,81 * *$ & 0,830 & $1,63^{\mathrm{ns}}$ & $\begin{array}{l}\text { Regretion is very } \\
\text { significan/ } \\
\text { Linearity Regretion }\end{array}$ \\
\hline $\begin{array}{l}\mathrm{Y} \text { atas } \\
\mathrm{X}_{3}\end{array}$ & $\begin{array}{l}\widehat{Y}=198,727+- \\
0,493 X_{3}\end{array}$ & 38,28 & $6,81 * *$ & 1,495 & $1,65^{\mathrm{ns}}$ & $\begin{array}{l}\text { Regretion is very } \\
\text { significan/ } \\
\text { Linearity Regretion }\end{array}$ \\
\hline
\end{tabular}

Tabel 8. Linierity Testing and Significan

After fulfilling the requirements of the analysis, the research hypothesis test was done. The summary of the hypothesis test results can be seen in the following Tables and figures 


\begin{tabular}{|l|c|l|l|l|}
\hline Direct Effect & $\begin{array}{c}\text { Line } \\
\text { coefficient }\end{array}$ & $\mathbf{T}_{\text {calculate }}$ & $\mathbf{t}$ table & \multicolumn{1}{c|}{ Test Result } \\
\hline $\mathrm{X}_{1}$ to $\mathrm{Y}$ & $-0,245$ & $-3,10$ & $-1,98$ & $\begin{array}{l}\mathrm{H}_{0} \text { rejected, } \mathrm{H}_{1} \text { accepted. There } \\
\text { is negative direct effect } \mathrm{X}_{1} \text { to } \mathrm{Y}\end{array}$ \\
\hline $\mathrm{X}_{2}$ to $\mathrm{Y}$ & $-0,261$ & $-3,35$ & $-1,98$ & $\begin{array}{l}\mathrm{H}_{0} \text { rejected, } \mathrm{H}_{1} \text { accepted. There } \\
\text { is negative direct effect } \mathrm{X}_{1} \text { to } \mathrm{Y}\end{array}$ \\
\hline $\mathrm{X}_{3}$ to $\mathrm{Y}$ & $-0,256$ & $-3,43$ & $-1,98$ & $\begin{array}{l}\mathrm{H}_{0} \text { rejected, } \mathrm{H}_{1} \text { accepted. There } \\
\text { is negative direct effect } \mathrm{X}_{1} \text { to } \mathrm{Y}\end{array}$ \\
\hline
\end{tabular}

Table 9. The summary of the hypothesis test results

Information:

Significan $\left(t_{\text {calculate }}>t_{\text {table }}\right.$ pada $\left.\alpha=0,05\right)$ positive effect

Significan ( $\mathrm{t}_{\text {calculate }}<\mathrm{t}_{\text {table }}$ pada $\left.\alpha=0,05\right)$ negative effect

Very Signifikan $\left(\mathrm{t}_{\text {calculate }}>\mathrm{t}_{\text {table }}\right.$ pada $\left.\alpha=0,01\right)$ positive effect

Very Signifikan ( $t_{\text {calculate }}<t_{\text {table }}$ pada $\left.\alpha=0,01\right)$ negative effect

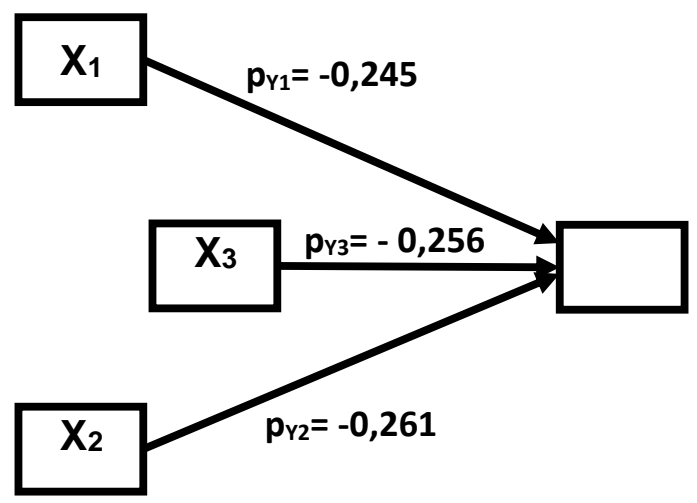

Figure2 Research Result Line Coefficient

\section{Discussion and Conclusion}

\section{Reward Effects Negative Direct on Turnover Intention}

Based on the results of the first testing hypothesis, it could be concluded that there was a negative direct effect of the variable rewards toward Turnover Intention variables with a correlation coefficient of -0.476 and a path coefficient value of -0.245 . This number gives the meaning that the reward has a direct negative effect toward Turnover Intention.

Thus, it could be seen that to reduce Turnover Intention of teachers in SMP S, Rokan Hulu Regency can be done by increasing reward or the teachers. The results of this study were correlated with the statement of rewards to affect such as individual behaviors as turnover, absenteeism, performance, and commitment (Gibson et.al, 2012).

The results of the study indicated that other salary / incentive indicators are indicators with the highest achievement, which is equal to $26.06 \%$. Based on these achievement figures, the main thing that can be done to reduce of Private Junior High School teacher turnover intention in Rokan Hulu Regency is to provide better salaries / incentives. The principal and the education 
office should be able to increase the salary / incentives received by the teacher. Economic, social service and technological, managerial, student characters, teaching related and environmental factors in descending order are the reasons for the teacher turnover in the university (Minda, 2015).

The results of the study also showed that other incentives in schools were the highest achieving items, which were 4.23. Based on the results of the study, it is specifically known that to reduce Turnover Intention for the teachers at junior high school in Rokan Hulu Regency can be done by increasing teachers. Other incentives are income received besides salary.

The salaries of teachers at privat junior high scholl based on the number of hours taught. By knowing the number of teaching hours, the teacher of course already knows the amount of salary they receive for one month. The amount of other incentives for which the amount and time of receipt are not known with certainty will certainly make teachers less willing to turnover from school.

Achieving teachers are given a greater opportunity to take part in activities related to their competencies which are also dominant items. Based on these findings, so that the teacher's turnover intention can be reduced, the principal and the education office should provide opportunities for outstanding teachers to take part in activities related to their competencies. As teachers are included in competitions between teachers and so on. Recognition of achievements is certainly very important for the teacher.

Associated with the highest achievement of the variable turnover intention, it was concluded that the lack of opportunities for teachers in participating in activities related to their competence resulted in the teacher's opinion that his current profession was not right for him. This opinion will trigger the emergence of the desire for teacher turnover intention.

The findings of this study are also supported by the results of Hirpassa's Motuma study which stated seven teacher turnover factors. Turnover is caused by economic factors, social and technological services, managerial factors, student character factors, factors of fellow teacher relations, initial opinion factors and environmental factors (Minda, 2015).

\section{Motivation effects Negative Direct toward Turnover Intention}

The results showed that there was a negative direct effect of Motivation variables on Turnover Intention variables with a correlation coefficient of -0.475 and a path coefficient value of 0.261. This number gives the meaning that Motivation Direct Negative Influence on Turnover Intention.

Thus it is known that to reduce Turnover Intention of private junior high school teachers at Rokan Hulu can be done by increasing teacher motivation. Because they show high levels of motivation, commitment and organizational citizenship, they adopt better performance, leading to lower absenteeism and turnover rates, increased productivity and higher levels of quality (Armstrong, 2011). Furthermore, it is also known that teacher motivation influences students' abilities (Molavi, Biria \& Chalak, 2018).

The results of the study indicate that the indicator with the highest achievement is an indicator of knowing the direction in work. In order for the teacher not to have the desire to quit his job, their knowledge must be improved on the direction of work. Increasing the knowledge of direction in work can be done by both the teacher and the school or service. The achievement 
of the indicators of knowing the direction in work is $26.38 \%$. The way to increase knowledge of direction in work can be done by providing an understanding of the main tasks of the teacher in accordance with the National Education System Law.

Judging from the items on the indicators knowing the direction of work as well as the overall indicator, the point I teach students to live healthy is an item with a high achievement, which is 4.38. This data shows that reducing the S Middle School Turnover Intention in Rokan Hulu Regency can be done by increasing the teacher's understanding of the direction of their work, especially in providing students with an understanding of healthy living. Teachers should provide examples and teach healthy lifestyles to students because this is part of the purpose of education it self. Teacher motivation can be improved by improving the teaching environment both in the physical and professional environment (Pourtoussi, Ghanizadeh \& Mousavi, 2018) Associated with the highest point of turnover intention, it was concluded that the teacher's understanding of the direction of work, especially in realizing healthy living students, could reduce the teacher's assumption that the profession was not a suitable job for them. The direction of work is very important to be understood by the teacher at work. The teacher will be motivated when he knows more about the purpose or direction of the work being done compared to not understanding the direction of his work. Loss of motivation will lead to high turnover desires. If motivation is lost, performance is degraded and this leads to mental problems, absenteeism and turnover (Vnouckova and Klupakova, 2013)

\section{Job Satisfaction Affects Negative Direct on Turnover Intention}

The results showed that there was a negative direct effect of Job Satisfaction variables on Turnover Intention variables with a correlation coefficient of -0.455 and a path coefficient value of -0.256 . This number implies that Job Satisfaction Directly Affects Negative on Turnover Intention.

Thus it is known that to reduce the Turnover Intention of private Junior High School Teacher in Rokan Hulu Regency can be done by increasing teacher Job Satisfaction. found that both satisfaction and commitment to independent turnover intentions and cognitions, which in turn are almost all of their impact on turnover. The function was correlated with intentions rather than commitment, while reverse held true for actual turnover (Anderson \& Viswesvaran, 2001). Furthermore, the teacher satisfaction factor is firstly, feel able to effectively establish behaviour and communication rules in their classrooms, secondly, respond to students' expectations and cooperate with parents and the school administration, thirdly, are supported by colleagues and educational services and, fourthly, share experiences in a collegial atmosphere. Job dissatisfaction, on the contrary, is reported to derive firstly from Curricula restrictions, secondly from a lack of specialized knowledge about teaching, and thirdly from the lack of a reliable assessment procedure (Koutrauba and Michala, 2017)

Judging from the Job Satisfaction variable, the indicator with the highest achievement is satisfied with the style of the principal and supervisor. This indicator is $26.07 \%$. Based on these data, it is known to reduce junior high school teacher's S Turnover Intention in Rokan Hulu Regency can be done by increasing teachers' satisfaction with the style of principals and supervisors. 
Judging from the instrument items indicators satisfied with the style of principals and supervisors, then the item with the highest achievement was the assessment of the principal for teacher performance (4.50). Based on this item, it is known to reduce Turnover Intention of Private Junior High School in Rokan Hulu District can be done by increasing teachers' satisfaction with the assessment of their performance by the principal.

Fair and transparent performance assessments will provide teachers with satisfaction with the principal. This satisfaction will reduce the desire for teacher turnover. The school principal should carry out performance appraisal in accordance with the applicable rules of regulation. The principle of transparency and fairness is absolutely owned by the principal in providing teacher performance appraisals. Teachers who feel imposed unfairly will have the desire to leave work. The desire that continues to be fostered will certainly result in real action coming out of school.

Associated with the achievement of the highest point of turnover intention, it can be concluded that the better the teacher's perception of the performance assessment by the principal can reduce their assumption that the teaching profession is not a suitable job for them. Teachers who obtain good performance appraisals from the principal will assume that the teaching profession is suitable for them. These results provide empirical evidence that job satisfaction (X2) has the proposed hypotheses H5 is accepted. It means that intention turnover will decrease, if job satisfaction increases. Conversely, intention turnover will increase, if job satisfaction decreases (Chalim, 2018)

\section{ACKNOWLEDGEMENTS}

Thanks to LPDP Ministry of Finance who has given scholarship to the author to continue education and help financing the publication of this paper.

\section{REFERENCE}

[1]. Anderson, Ones Sinangil \& Viswesvaran. (2001). Handbooks of industrial, Work \& Organizational Psychology, London: Sage Publication.

[2]. Armstrong, Michael. (2009). Armstrong's Handbook of Human Resource Management Practice. 11th Edition. Kogan Page.

[3]. Armstrong, Michael. (2011). A Handbook of strategic Human Resource Management. 5th Edition. Kogan Page.

[4]. Cao, Zhoutao., Chen, Jinxi., Song, Yixiao,. (2013). Does Total Reward Reduce the Core Employees Turnover intention?. International of Journal Business and Management, 8 (20), 62-75.

[5]. Chalim, Asep Syaifudin. (2018). Effect of Job Insecurity, Organizational Commitment, Job Satisfaction on Turnover Intention : A Case Study of Newcomer Lecturers at Private Islamic Universities in Eas Java Province, Indonesia. Journal Peuradeun, 6 (2), 199-214.

[6]. Duraisingam, Vinta., Pidd, Ken \& Roche, Ann. (2009). The Impact of Work Stress and job Satisfaction on Turnover Intention: A Study of Australian Specialist Alcohol and Other Drug Workers. Journal Informa Healthcare, 16 (3), 217-231.

[7]. Gibson, James L., Ivancevich, John M., Donelly Jr, James H \& Konopaske, Robert. (2012). Organizations, Structure, Processes. 14th Edition. New York: McGraw Hill Irwin. 
[8]. Gilley, Ann., Gilley, Jerry W., Quatro, Scott A \& Dixon, Pamela. (2009). The Praeger Handbook of Human Resource Management. Vol 1 \& 2. USA: Greenwood.

[9]. Gobena, Gemechu Abera. (2018). Factors Affecting In-Service Teachers' Motivation: Its Implication to Quality of Education. International Journal of Instruction. 11 (3), 163-178.

[10]. Griffin, Ricky W \& Moorhead, Gregory. (2014). Organizational Behavior Managing People and Organizations. South Western Cengage.

[11]. Ilgen, Daniel R \& Sheppard, Lori. (2001). Work Motivation in The Context of A Globalizing Economy. Edited by Miriam Erez, Uwe Kleinbeck and Henk Thierry. Lawrence Earlbaum Associates.

[12]. Imran. (2017). Impact of Intrinsic Factors of Motivation on Employee's Intention To Leave: A Case Study of Health Departement District Okara Punjab, Pakistan. Arabian Journal of Business and Management Review, 7 (3), 2-8.

[13]. Ingersoll, Richard. (2001). Teacher Turnover and Teacher Shortages: An Organizational Analysis. American Educational Research Journal, 38 (3), 500-534.

[14]. Jex, Steve M. \& Britt, Thomas W. (2008). Organizational Psychology A Scientist Practitioner Approach. 2nd Edition. USA: Willey.

[15]. Khan, Alamdar Hussain \& Aleem, Muhammad. (2014). Impact of job satisfaction on employee turnover: An empirical study of Autonomous Medical Institutions of Pakistan. Journal of International Studies, 7 (1), 122-132.

[16]. Koutrouba, Konstantina \& Michala, Myrto. (2017). Professional Satisfaction of Secondary Education Teachers: The Case of Greece. International Journal of Instruction. 10 (2), 85-102

[17]. Kwame, Kunu Etornam., Mahama, FranÇois., Boahen, Patience Ama Nyantakyiwaa \& Denu, Mathias Kofi Worlanyo. (2017). The Effect of Employee Turnover on the Performance of Zoomlion Ghana Limited. Journal of Business and Economic Development, 2 (2), 116-122.

[18]. Locke, Edwin A. (2009). Handbook of Principles of Organizational behavior. Indispensable Knowledge for Evidence Based management. 2nd edition. Edited by John A. Locke. Wiley and Sons.

[19]. Loeb, Susanna., Darling-Hammond, Linda \& Luczak, John. (2005). How Teaching Conditions Predict Teacher Turnover in California Schools. Peabody Journal of Education, 80 (3), 44-70.

[20]. McCoy, Thomas J. (1992). Compensation and Motivation Maximizing Employee Performance With Behavior Based Incentive Plans. AMACOM Books.

[21]. Mendis, M.V.S. (2017). The Impact of Reward System On Employee Turnover Intention: A Study On Logistics Industry of Sri Lanka. International Journal of Scientific \& Technology Research, 6 (9), 67-72.

[22]. Minda, Motuma Hirpassa. (2015). A Study of Magnitude and Causes of Turnover Among Academic Staffs of Ethiopian Higher Institutions: Evidence From Ambo University. Journal Star, 4 (3), 285-293.

[23]. Molavi, Ahmad., Biria, Reza \& Chalak, Azizeh. (2018). Effect of Teacher Motivational Practices and Student Demotivation on Request and Refusal Speech Acts Produced by Iranian EFL Learners. International Journal of Instruction. 11 (3), 347-362.

[24]. Pilbeam, Stephen \& Corbridge, Marjorie. (2006). People Resourcing Contemporary HRM in Practice 3rd Edition. England: PEL.

[25]. Pourtoussi, Zahra., Ghanizadeh, Afsaneh \& Mousavi, Vahid. (2018). A Qualitative In-depth Analysis of the Determinants and Outcomes of EFL Teachers' Motivation and Demotivation. International Journal of Instruction, 11 (4), 175-190. 
[26]. Robbins, Stephen P., Judge, Timothy A., Hasham, Elham S., (2012). Organizational Behavior. Arab Edition. England: Pearson.

[27]. Robbins, Stephen P \& Judge, Timothy A. (2013). Organizational behavior 15th Edition, New Jersey: Pearson.

[28]. Sajjad, Asif., Ghazanfar, Hassan \& M. Ramzan. (2013). Impact of Motivation on Employee Turnover in Telecom Sector of Pakistan. Journal Of Business Studies Quarterly, 5 (1), 76-92.

[29]. Torrington, Derek., Hall, Laura., Taylor, Stephen. (2005). Human Resource Management 7th Edition. England: Prentice Hall.

[30]. Tnay, Evelyn., Abg Othman, Abg Ekhsan., Siong, Heng Chin., Lim, Omar Sheilla Lim. (2013). The Influences of Job Disatisfaction and Organizational Commitment on Turnover Intention. Procedia Social and Behavioral Sciences, 97, 201-208.

[31]. Vnouckova, Lucie \& Klupakova, Hana. (2013). Impact of Motivation Principles on Employee Turnover. Journal Ekonomicka Revue, 16, 79-92.

[32]. Youcef, Saida Souar., Ahmed, Setti Sid., Ahmed, Boussahmine. (2016). The Impact of Job Satisfaction on Turnover Intention bythe Existence of Organizational Commitment, and Intentto Stay as Intermediates Variables Using approach PLS inSample Worker Department of Transport. Journal Management, 6 (6), 198-202. 